\title{
An integrated and experience-based approach to social work education: The Newcastle model
}

\author{
JILL GIBBONS (PhD) and MEL GRAY (PhD) \\ University of Newcastle, New South Wales, Australia
}

\begin{abstract}
The paper describes a unique social work education model developed by a group of social work practitioners, all but one of whom were new to academia. The University of Newcastle, in New South Wales, pioneered problem-based learning (PBL) in Australia. The social work program adopted PBL and gave it a strengths focus, making experience and experiential learning central to its approach. Newcastle's model is based on the belief that learning to be good social workers is best achieved through learning by doing, working with students' experiences, integrating theory and practice, using a collaborative or small group approach, and locating these elements in a strong social justice context. The Bachelor of Social Work (BSW) degree is relatively new. Introduced in 1991, its first graduates entered the workforce in 1995. The Newcastle model provides a unique example of experience-based learning and an integrated approach to social work education.
\end{abstract}


The paper describes a unique social work education model developed by a group of social workers at the University of Newcastle, in New South Wales, which pioneered problembased learning (PBL) in Australia. The social work program adopted PBL and gave it a strengths focus, making experience and experiential learning central to its integrated and experience-based approach to social work education. The Bachelor of Social Work (BSW) degree was introduced in 1991 and its first graduates entered the workforce in 1995.

Newcastle's model is based on the belief that learning to be good social workers is best achieved through learning by doing, working with students' experiences, integrating theory and practice, using a collaborative or small group approach, and locating these elements in a strong social justice framework. The central question in an experience-based model of education is not 'what to teach?' but 'how students learn?' The founder members of the Newcastle social work program believed from the outset that a focus on the way students learn was particularly relevant to a world that was changing so quickly that educational content became obsolete before students graduated (English, Gaha \& Gibbons, 1994). Rogers (1980) believed one of the qualities needed for individuals to survive in a rapidly changing world was openness to new experiences, ways of seeing and ideas, and to unfamiliar concepts. He saw people of the future as process people who were 'keenly aware that the one certainty of life is change - that they are always in process, always changing. They welcome this risk-taking way of being and are vitally alive in the way they face change' (p. 351). 
The paper begins with a review of the theory informing the experience-based model and the factors influencing its development. It then describes the main elements of the model and the challenges of teaching and learning it presents. It ends with a brief comment on future directions.

\section{Theory informing experience-based education}

Theories of experience-based education, the origins of which are attributed to Dewey (1859-1952), the American philosopher and educator, informed the Newcastle approach. Dewey is credited with being the first educator to suggest a change of focus from what people learn to how learning takes place, from the content to the process of learning. Dewey's concerns with interaction and environment, reflection and experience, and community and democracy, were very similar to social work concerns (Dewey, 1916, Dewey, 1938). There was a close association between Dewey and Jane Addams (18601935), a pioneer of social work. Dewey was one of seven on the first board of trustees at Hull House (the settlement project in Chicago) and a close associate of Addams, whose ideas paralleled and supported his educational theories. 'It is difficult to say whether Dewey influenced Jane Addams or Jane Addams influenced Dewey. They influenced each other and generously acknowledged their mutual obligations. Hull House and Dewey's experimental school at the University of Chicago constantly exchanged ideas and personnel’ (Lasch, 1965, p. 176).

In the first half of the twentieth century, Dewey's radically different ideas about education were being developed in parallel to the emergence of social work education. There are some clues that social work courses more in line with Dewey's ideas existed 
during the 1920s (Robinson, 1930), but it is not clear what became of these. There have always been alternative visions of education. For instance, Socrates saw the role of the teacher as that of a mentor and wanted to develop learners as questioners. It is interesting therefore, to consider how the dominant model of social work education conformed to the traditional didactic style of imparting knowledge. Freire (1970) referred to this as a 'banking' concept, in which the teacher was the expert 'depositing' knowledge into the empty 'accounts' of students, to be stored and drawn on by them when required

Dewey's educational philosophy incorporated five core ideas, among them a recognition of the distinctive worth and capacity of every individual; educating each person to become significantly engaged in contexts of social action and experience; the importance of students achieving multiple and different understandings of their world; and the insistence that learning was a lifelong endeavour and commitment (Knefelkamp \& Schneider, 1997). Dewey's work was acknowledged as a major inspiration for the experience-based education theories of Boud, Kolb and Schön, all of which were influential in the development of the Newcastle model (Boud, 1985, Boud \& Pascoe, 1988, Boud \& Knights, 1996; Boud \& Miller, 1996; Kolb, 1984; Schön , 1983, 1987)

Kolb (1984) began his book Experiential learning: Experience as the source of learning and development, by describing how his model was informed by three different sources: Dewey's ideas on experience-based education, the group research of Lewin, and the cognitive learning theories of Piaget. Kolb’s reference to Piaget alluded to Piaget's role in challenging behaviourism and developing constructivism by seeing the learner as an active creator, rather than a passive recipient, of new knowledge. This constructivist or 
cognitive perspective viewed knowledge as active, rather than inert, and as situated in lived worlds:

Constructivist learning is based on students' active participation in problem-solving and critical thinking regarding a learning activity which they find relevant and engaging. They are 'constructing' their own knowledge by testing ideas and approaches based on their prior knowledge and experience, applying these to a new situation and integrating the new knowledge gained with pre-existing intellectual constructs (Briner, 1999).

While valuing experience-based learning, Knefelkamp and Schneider (1997) provided a critique of Kolb and his contemporaries, arguing that they focused on the individual learner. In so doing, Knefelkamp and Schneider claimed that Kolb marginalised the original ideas of the model as developed at the beginning of the $20^{\text {th }}$ century by Dewey, Addams, du Bois, and James, which placed experience-based learning clearly in a context of social justice and social change. Knefelkamp and Schneider proposed that it was time to reinstate the social responsibility focus of the model. Newcastle's model of social work education has always had a strong social justice focus, consistent with the original experience-based pedagogy .

Experiential learning models ground the learning task at the level of the person-insituation. They work from the bottom up. They make experience central to learning in the belief that people learn best by doing. They make learning a reflective exercise, the 
thinking resulting from the initial response to the experience. Important aspects of experience-based learning are to engage the learner's experience and, acknowledging that learners construct their own meanings from their own personal and cultural history, to challenge their interpretations and offer alternative ways of viewing knowledge (Boud \& Knights, 1996). The experience-based approach at Newcastle began with Kolb’s (1984) four-stage model: Learners undergo a concrete experience, reexamine and reflect on that experience, formulate abstract concepts and generalisations from their reflections, and then test these in new situations. Figure 1 shows the way in which the Newcastle model has adapted Kolb’s model.

Insert FIG.1.

Knefelkamp and Schneider (1997) placed Kolb’s model in a social framework, which they saw as being in line with the original ideas of experience-based education. Their concept of education is that it seeks to engage people in citizenship and a striving for social justice. The experience or 'trigger' is seen as needing the learner to engage in multiple experiences, standpoints and aspirations, rather than a personalised, individual experience. They see outcomes as both capacities that learners develop through practice and mentoring (empathy, judgment, fairness and risk-taking) and through sustained commitment (care, wisdom, justice seeking and courage). This development of Kolb’s model seems particularly in line with the way in which experience-based learning has been located in a social justice framework in the Newcastle program. 
Boud and Knights (1996) proposed a number of key factors in experience-based learning that were found to be pivotal in the successful application of the model:

- The learner's own experience must be engaged. This is expressed in Newcastle's experience-based focus.

- Learners construct their own meanings from their own personal and cultural history. The role of the teacher as facilitator is to challenge these interpretations and offer alternative ways of viewing knowledge. This is also the strength of working in small groups where alternative ways of viewing experience and knowledge are shared. It is this which gives the Newcastle model its constructivist focus.

- Learning is holistic and integrated. Theory and practice, the individual and society, art and science, are not separated but are considered as a whole. The role of the teacher as facilitator is to assist learners to make links between different kinds of experience and to make connections between areas of knowledge. As well as being a foundation of learning, experience can also distort, constrain, and limit meaning, so the facilitator's role is to challenge interpretations of experience and to foster this process in the group environment used in Newcastle’s model.

There is integration in the synchronicity between the approach to learning and the learning relationship, and the social work profession itself. Both social work and experience-based learning focus on the person in the situation, on process rather than content, on creating a safe place for exploration and change, and on freeing individuals, groups or communities to look at alternative ways of viewing the world and of dealing with their problems. The vital 
importance of the small group in an experience-based model, as well as in the development of critical reflection, was another area of commonality with social work and a reason why social workers were likely to have particular skills to bring to an experience-based program. In his text on developing critical thinkers, Brookfield (1987) observed that:

There are many points of connection between critical teaching and various forms of therapy, counselling, and social work. The emphasis on becoming aware of takenfor-granted assumptions informing behaviour, the focusing on people's perceptions of their own experiences, the encouraging of group scrutiny of relevant issues, and the presentation of alternative interpretations of reality are aspects of therapeutic and counselling roles that would be familiar to most teachers of critical thinking' (p. 80-81).

Brookfield (1987) described critical thinking as 'calling into question the assumptions underlying our customary, habitual ways of thinking and acting and then being ready to think and act differently on the basis of this critical questioning' (p.1). As such, critical thinking is the basis for liberal education and for a profession such as social work that claims, as its business, the achievement of personal and social change.

Freire (1970) saw education as the means for overcoming oppression and social inequality. Education, in the way that he envisaged it, enabled learners to break free from habitual patterns of thought and socialised beliefs to view their worlds in new ways. In Pedagogy of Hope, his revisiting of Pedagogy of the Oppressed, Freire (1994) valued an 
experience-based approach to learning but noted that 'the uncritical celebration of experience needs to be avoided' (Boud \& Miller, 1996, p.9). In other words, he recognised that learning from experience needed to take place within a context of good critical thinking skills or critical reflection. He described effective critical teachers as needing to have competence (particularly in communication and group facilitation), courage to persevere in challenging assumptions, humility especially in resisting a guru status as a teacher, political clarity in the capacity to break free from dominant paradigms, and to be prepared to take risks in order to creatively engage students in the excitement of learning (Freire, 1994).

The phases of critical thinking described by Brookfield (1987) parallel the experiential learning stages of Kolb’s (1984) model. Brookfield's phases begin with the trigger event, which prompts a sense of inner discomfort and perplexity. This is followed by an appraisal or a period of reflection involving self-examination and clarification of concerns, exploration or looking for new ways of understanding or interpreting the event, testing options, being open to new information, looking for new ways of acting, developing alternative perspectives, making sense of the new material, and deciding on new actions to take. Finally, there is integration of the new knowledge or putting into practice the new ways of thinking and acting.

Fook (1999) wrote about the role of experience in the critical reflection process, which she saw as essential for learning. Critical reflection required that people placed themselves directly in the situation and examined their own experience. This selfexamination included scrutiny of personal reactions and interpretations, social and cultural 
background, and emotions. It required humility in thinking that Gambrill (1997) referred to as a specific quality of critical thinking.

\section{Influences on the Newcastle model}

The University of Newcastle pioneered problem-based learning in Australia and the impetus for an experience-based social work program was provided by the way in which the model had evolved within the School of Medicine. Brian English (English et al 1994), the foundation professor of social work, drawing on the experience in medicine and his own reading of the work of Kolb (1984), Boud (1985, 1988), and Schön (1983 \& 1987), compiled seven central principles. These became pivotal to the new social work program. They were:

1. Exploration and discovery - The acquisition of knowledge: Through a process of exploration and discovery, students would learn the types and sources knowledge that informed social work practice and ways in which to acquire knowledge and produce information.

2. Critical reasoning and analysis - The process of thinking: Students would learn to think logically and laterally to develop skills in assessment, judgment and argument and the means for arriving at an understanding of available information. They would be encouraged to think laterally and creatively in looking for new ways of understanding. 
3. Feeling and evaluation - The search for meaning: Students would learn to assess the quality, importance and relevance of information, to judge the integrity of sources and assess the meaning of situations for the persons involved.

4. Communication - Sharing information and conveying meaning: Students would learn to be sensitive, to read and to respond accurately to what was going on in a situation. Good communication skills would be taught as the means to receive and convey signals verbally and non-verbally, using a range of spoken, written, visual, audio, and other media.

5. Intervention - Taking or sharing in action: Students would learn that competent professional practice involved taking action with clients, using knowledge, developing understanding, evaluating situations, and communicating with others in a social, political and economic context. Due regard would be paid to ethical considerations necessary to bring about change that was in the best interests of clients.

6. Professional approach to work - Processing work through time: Students would learn to organise their work as individuals, in teams, or in a larger organisation. They would learn to deal with organisations and systems generally, and to manage their workload in ways that would enhance their practice, enrich their own lives, and which did not lead to any harm for their clients, their colleagues or themselves.

7. Self-directed learning - Preparation for a lifetime of learning: Students would learn that learning was a lifelong process and that, as practising professionals, they needed to develop their ability to go on acquiring knowledge, developing skills, exploring values, and adapting to change. Self-directed learning included recognising learning 
opportunities, self-monitoring, participating in professional supervision sessions, and setting and working towards self-learning goals.

These central principles determined the future direction of the program as attention was paid to the following:

- The integration of reflective practice and critical thinking with experiential learning

- Recognition of learning as a lifelong process

- Belief in the value of self-directed learning

- The desire to integrate field practice and theory or campus-based learning

- Recognition of the synergy between experience-based learning and action research.

The integration of reflective practice and critical thinking with experiential learning (see Plath et al, 1999)

Reflective and critical thinking skills were seen to be an essential part of the experiencebased model envisaged by Dewey and developed by Kolb (1984), Schön (1983, 1987), and Boud et al (1985, 1988, 1996).

\section{Recognition of learning as a lifelong process}

Many writers in the experience-based approach have emphasised learning as a lifelong process, which was given impetus with a UNESCO report in 1972 (Faure, 1972). It is difficult to conceive that in 1972, lifelong learning was seen to be a radical idea. 
Belief in the value of self-directed learning

In contrast to a behaviourist belief that learning would only occur if there were external rewards (or punishments for not learning), self-directed learning proposed that adult learners were motivated by various internal incentives, including a need for self esteem, curiosity, a desire to achieve, and the satisfaction of accomplishment (Knowles, 1975).

The desire to integrate field practice and theory or campus-based learning

While the field experience or practicum is vital to learning, the Newcastle model has not made the 'field the classroom' as advocates of a pure experiential model suggest it should be. For instance, Goldstein (2001) argues that 'we need to turn to the field as the educational setting where we can explore what, specifically, students need to learn and know' and 'then consider how the academic classroom can support the field with the knowledge that is directly relevant to practice with people' (p.4) in the immediate situation. The Newcastle model has brought the field into the classroom by engaging client groups and practitioners as educators, drawing on the life experiences of students, contracting client groups to design classroom simulation exercises, making maximum use of secondary sources of experience available in documentaries, films, plays, autobiographies, biographies and literature, as well as using the experience of the group in its undertaking of the learning tasks. 
Recognition of the synergy between experience-based learning and action research

The Newcastle course began and has continued from an action research approach. It was recognised that action research and experience-based learning shared common attributes, particularly moving between creative problem-solving, implementation of practice, and reflective interpretation of practice (Maudsley \& Strivens, 2000).

\section{The way in which the action research has informed course development}

At the initial design stage, existing norms of social work education were acknowledged but set aside. Members of the planning group drew on their extensive experience as social work practitioners as well as their experience of social work education as students. How had the courses they had studied equipped them for practice and how had they left them illprepared? What was the major learning they had to accomplish in practice? What were the strengths and weaknesses of social work practice that could be addressed at the educational level? From critical reflection on their own education and practice, the original academic group developed a set of goals and principles for the new four-year course. They identified that good social work practice incorporated the following elements:

- An awareness of larger social issues that arises from work with people and that leads to an involvement in working for community or social change.

- Good interpersonal skills, including genuineness, warmth and compassion.

- Sound self-discipline, knowledge of theory, research, and legislation in one's area of practice, demonstrated by competence in fulfilling essential tasks. 
- A high level of critical reflection involving questioning, creative problem solving, freedom of thought, and preparedness to examine one’s own values, assumptions, and biases.

- Capacity for exploring new possibilities in practice through innovation, risk taking, and research.

- Effective organisational skills displayed through teamwork, leadership, assertiveness, and negotiation.

- Commitment to the values and ethics of the profession.

- Positive and confident social work identity.

The components of learning for practice, and goals and principles developed from the critical reflection on experience were then structured into a four-year Bachelor of Social Work degree program (see Appendix 1) based on a pedagogy that incorporated the following:

- Experience-based learning.

- An explicit social justice value framework.

- An integrated approach, which did not separate theory and practice subjects or levels of intervention and included a close relationship between campus and field learning.

- A constructivist perspective.

- A self-directed approach to learning in preparation for lifelong learning.

- An emphasis on critical thinking and critical reflection.

- Small groups as the milieu in which learning would take place. 
- The teacher's role as facilitator.

- A team approach to curriculum development and teaching.

- An action research model of course development.

Camp (1996), referring to problem-based medical education, noted the tendency to 'water down' the new approach over time. She believed that the essential features of a problembased model were that students worked in small task groups, learning material was not separated into 'discipline specific' areas and the teacher did not maintain absolute control over what was learned. This could not be achieved by keeping much of the instruction in a traditional format (lectures or labs) or when assessment focused primarily on content acquisition. Camp also criticised the practice of 'burying' problem-based learning components in traditional courses, believing that when this happened students lost the time for independent study.

This 'watering down' has not happened at Newcastle. In fact, in the ten years of the program's existence, the model has become more deeply entrenched as a result of the action research approach to curriculum development. The social work team continues to identify points of improvement and each class taught leads to further refinement and development. Over time, staff members have developed considerable expertise in teaching experientially. The core elements of the Newcastle model are discussed briefly below. It is not possible within the scope of this paper to develop each element to its fullest extent. Rather an attempt is made to show the uniqueness of our model. 
Staff and students engage in a continuous process of critical reflection and evaluation of the process through end of semester reviews and yearly or twice yearly planning retreats. At these retreats feedback from staff and students about what has or has not worked and innovations in the program to address concerns of staff, students, and practitioners (as field educators or employers), are intensely discussed and new ideas are incorporated into the following year's program. This process is informed by outcomes, on whether students have achieved the specified learning goals and on their feedback regarding the learning experience. To illustrate the Newcastle approach, an example of a learning unit at the beginning of the second year of the program is provided in Appendix 2.

There are ongoing issues with which staff members grapple. Models of assessment in experience-based education present a persistent challenge. The necessarily authoritarian role of the assessor cuts across the learner-facilitator relationship fostered in the program. The sudden experience of their coach or mentor as judge can confuse or anger students. Other models of assessment that have been tried, such as self-assessment or peer assessment, have been found wanting. The provision of effective feedback to students on assessment tasks aids their learning but does not dilute the painful experience of being graded. Electing for ungraded passes does not allow students to have feedback about their relative performance in particular tasks.

\section{Experience-based Learning}

In an experience-based model, prior learning and experience are taken into account. Peer experience is regarded as a valuable asset. Students make decisions about and take 
responsibility for their own learning. Through self-directed and group-negotiated learning facilitated by their teachers or lecturers, students become active participants in the learning process. An experience-based model focuses on the learning process. Course content arises from the specific context in which the learning takes place, the needs of the learner, and the purpose or goals of the learning unit. Experience-based learning represents a shift away from didactic teaching in which students make few decisions about their learning and assume a relatively passive role as consumers within a framework that promotes dependence on their teachers. These differences are summarised in Figure 2.

Insert FIG. 2.

An experience-based model of social work education is not without problems. There is always a struggle to avoid slipping back into the traditional banking style of education and a directive, authoritarian approach. Students are often more comfortable with the didactic approach, in which they have less responsibility, and it is tempting to believe that students will only acquire information if it is shoveled into them. It is important to continue to be aware of the challenge that is experienced by students and teachers in their transition from traditional models of learning. In each year of the program staff begin with an overview of the model and allow students to reflect on and discuss the experience-based approach to learning. 
Experience- or problem-based learning models are resource intensive, especially in the establishment phase and in giving students adequate group and individual feedback to assist their learning. Finding trigger experiences that will successfully engage students and designing learning tasks that are immediately relevant (not only to the immediate learning situation but also within the wider practice and policy context) and at the same time capture the students' interest and attention, are a constant challenge. These elements are crucial to the way in which knowledge and skill acquisition is facilitated within the Newcastle model (as shown in Figures $1 \& 3$ ).

Traditional lecture theatres and classrooms with desks are not suitable. Students need to meet in large or small groups in a space that is comfortable and flexible. In this model two or three-hour class times are scheduled, with students required to attend, and resource staff available as needed. In first year, class time is five hours a week, increasing to ten hours a week in fourth year.

\section{A Social Justice Framework}

The Newcastle program has always made its value of social justice explicit and this is evident throughout the course. The commitment to social change and striving for a more equal society underlies almost all the learning activities. Learning units are structured as far as possible around current issues (Flynn, 1997). This is shown in Appendix 2 where students were required to develop skills in critical thinking, an understanding of ecological systems theory and community work theories and skills within the context of a learning unit on substance use. As part of the Community Drug Action Team, they were asked to 
develop a strategy to address the range of ideological perspectives in the community, the role of the community worker in implementing the strategy, the skills she might use, and the way in which the community would be engaged as participants. They were asked to apply their strategy to a current issue concerned with substance use, such as teenage drinking, ecstasy, injecting rooms, alcohol, and cigarette smoking, or with gambling. Their task was to collect five examples of Australian writing about the issue they identified which targeted different audiences, such as a popular newspaper, a 'serious' newspaper, letters to the editor in these papers, the internet, a professional journal, an alternative source, e.g. Green Left Weekly, and a government policy or report. They then had to analyse the different forms of writing in terms of the apparent values and ideologies of the publication or source, the intended audience, and the author. They were asked to include reflections on how these had influenced the approach taken in the material. Not only did students learn the dominant view (from the media) on the issue they identified, they also constructed an alternative critical view on the problem and how it might be dealt with at different levels of intervention, in keeping with an ecosystems perspective. To illustrate the creativity of the students, one group which chose the subject of gambling as their major issue, made T-shirts containing the 'facts' of the problem, calling for those who were getting rich on the weaknesses of others, to develop just interventions to deal with the problem.

\section{An Integrated Approach}

An integrated learning approach is used, that is, integration of theory and practice, the individual and social, art and science, field and classroom. Social work subjects are studied 
as a whole unit in each year. The learning is undertaken in a progressive series of learning units, each of which covers a number of themes and is built around specific goals and tasks. Learning is seen to be cumulative and tasks are designed to facilitate this incremental process. Over the four years of the degree, students work in small groups on a series of cases or situations similar to those they are likely to encounter in social work practice. The Newcastle model has recognised the need for the integration of field and campus-based learning. It has attempted to ensure that field education does not become marginal by requiring that all academic staff members are involved in field education. Students' field education experiences are used in classroom learning. Furthermore, practitioners play an important and active role in the teaching program.

To achieve this integration, new staff members, casual teachers (usually practitioners), and field education supervisors need to be trained to use the model. Both teachers and students need assistance with their transition from traditional models of learning, while at the same time, allowing them to be 'cross-cultural' as learners because they will continue to be required to undertake subjects in the traditional learning mode (The full degree program undertaken by Newcastle students is shown in Appendix 1. Only the social work subject is taught experientially).

\section{A Constructivist Perspective}

The constructivist perspective informs the Newcastle model on two levels in that students are taught a critical approach not only to their own understanding of the world but also to existing knowledge about the world. The active role taken by learners enables them to 
construct the learning experience not only in getting tasks done, but also in the sense that they construct meaning in terms of their own understanding and experience. Taking a constructivist perspective involves recognising that learners are not just passive recipients of information. It means helping them to identify ways in which they actively construct their knowledge in terms of their own prior experience and the meaning they attach to the people and situations they confront. It involves recognising that meaningful learning is that which is useful to real life situations. Thus the teacher as the coach or facilitator works strategically with students to help them gain this insight and awareness, by constantly working with them to apply learning to past or present experiences.

On the second level, students are taught to see knowledge as a social construction, situated within a cultural, historical, and local context. They are encouraged to gain a sense of its ever-changing quality and the need for constant learning to keep abreast of new knowledge and research. They also begin to understand uncertainty, ambiguity, and the unpredictability of human behaviour (Rossiter, 2001). Since social work is a diverse profession, it is impossible to teach students how to deal with every situation they might encounter. But it is possible to teach them to think on their feet, to be resourceful, to learn how to access knowledge, to conduct research, to network, and the like. This resourcefulness is invaluable in a world where knowledge changes rapidly and for a profession, such as social work, where so many of the problems and situations students encounter cannot and do not have predetermined outcomes. 


\section{Self-directed and Lifelong Learning}

This constructivist perspective reinforces the connection between experience-based and lifelong learning (Faure, 1972). The experience-based approach instils learning skills that students will use as they continue on their professional pathway and their journey through life. This happens, as Kolb (1984) proposed, when active learners take responsibility for their own learning. Self-directed learners are motivated by internal incentives, such as the need for self esteem, curiosity, desire to achieve, and satisfaction of accomplishment (Knowles, 1977) rather than external pressures to perform. Even though the Newcastle model is learner-driven, to the extent that students direct their own learning, it remains essential that a high level of staff support be provided since it has been recognised that, within problem-based models, self-directed learning can raise students' anxieties to an unreasonable extent (Finucane et al, 1998).

It is important to define the sense in which the term 'self-directed' is used within the Newcastle model. Facilitators provide learning goals to give the students clearly defined boundaries and an explicit focus, and to serve as learning outcomes for each academic year and curriculum unit. Students then direct the learning process within these parameters taking responsibility for tasks and assignments that are designed to assist in them in achieving their learning goals. There are times when the students determine their own learning goals, as when they do their practicum. At all times, lecturers are available to student task groups as well as to individual students as facilitators, resources, and mentors. All groups have facilitators to guide student learning. An emphasis is placed on helping students acquire the skills necessary for self-directed learning. These are literature search 
and appraisal, critical analysis, oral and written communication, teamwork, self-awareness, creativity, and self-esteem. Purists might consider use of the term 'self-directed' in this context a misnomer and might argue that group facilitated or group negotiated learning is a better description (Taylor, 1997). The sense in which we view learning as a self-directed process is summarised in Figure 3. Here it is shown that a trigger experience is provided to engage students' interest and to introduce the learning task. Students then negotiate with one another, working with the teacher as facilitator, how they will 'direct themselves and others in their group' to complete the task.

Insert FIG. 3.

Within the Newcastle model, the lecturers determine the content of the learning units. For the most part, students do not have a say in 'what they learn'. The learning material is goal and task focused but allows students, as far as is possible, to pursue their own individual interests. It is difficult to see how a fully self-directed learning model could feasibly operate in an outcome-focused context where there is limited time and a large number of students with a wide range of needs.

\section{Critical Thinking and Critical Reflection}

Learning from experience needs to take place within the context of good critical thinking skills or critical reflection. In the Newcastle model, critical thinking is seen to be an integral part of the experience-based learning approach. It is more than a step-by-step problem 
solving process or exercise in logic. Critical thinking is the actual application of reflective skills to real life situations, and can only be learned and refined through practice, through doing and reflecting on what we have done and why we did it that way (Brookfield, 1987). Vital to critical reflection and highly valued in the Newcastle model is creativity. We work hard to encourage students to think creatively by trying to imagine 'every which way' from which to view the problem or situation. This requires optimism (there is a solution), confidence (my ideas are good and worth sharing), acceptance of ambiguity and uncertainty (there are no hard and fast answers), wide ranging interests (bring everything I know to bear on this situation, the more wide ranging my interests, the more diverse my ideas will be), flexibility (there is more than one way to look at this situation), tolerance of complexity (I must understand all the elements at play), curiosity (I want to find possible solutions), persistence (I won’t give up ‘til I do), and independence (my ideas will add to those of others in my group). When we encourage students to think critically we are inviting them to think creatively, to come up with new ideas and innovative ways of solving problems. We recognise that creative thinkers:

- Reject standardised formats for problem solving.

- Are interested in a wide range of related and divergent fields.

- Take multiple perspectives on a problem.

- View the world as relative and contextual rather than universal and absolute.

- Frequently use trial and error methods in their experimentation with alternative approaches.

- Have a future orientation and embrace change optimistically. 
- Have self-confidence and trust in their own judgement (Brookfield, 1987).

Through experience-based learning we hope to develop social workers who are critical and creative thinkers ready to deal with the ambiguities and complexities of practice.

\section{Small Groups as a Medium through which Learning Takes Place}

Kolb (1984) noted that Lewin's T-group research in the 1970s established that learning was best facilitated in an environment where there was 'dialectic tension and conflict between immediate concrete experience and analytic detachment’ (p.9). A small group environment is an ideal context for experience-based learning and for the development of critical thinking skills. Figure 4 shows how this works within the Newcastle model.

Insert FIG. 4.

Working in small groups, students use a range of resources, including themselves, each other, academic staff, library and resource materials, knowledge and skills acquired in other subjects, and their own experience, in undertaking the learning task. In this way, they develop the appropriate social work knowledge and skills for their stage of learning, and they learn to examine the values relevant to the situation. They begin to study group dynamics, to respect and deal with difference, to challenge and be challenged, and to develop group facilitation skills. In this approach, students work on structured tasks under conditions that meet five criteria:

- Positive interdependence. 
- Individual accountability.

- Face-to-face interaction.

- Appropriate use of collaborative skills.

- Regular assessment of team functioning (Kaufman \& Felder, 2000).

Johnson, Johnson, and Smith (1998) found that, when implemented correctly, co-operative learning improved information acquisition and retention, higher-level thinking skills, interpersonal and communication skills, and self-confidence. The characteristics of our selfdirected small group experience-based learning model are summarised in Figure 5.

Insert FIG. 5.

Small groups are more than the 'milieu' in which learning takes place. They provide a context for interdependent learning (Taylor, 1997) and transactional dialogue (Brookfield, 1997). They provide a springboard against which students test their ideas, entertain the ideas of others, learn tolerance, acceptance, flexibility, and the like. The teacher as facilitator creates space for the development of this group process and ensures that the group remains a 'facilitative' learning environment. Exercising power in small groups, the occasional dominating or disturbed student can be harmful to other students. What duty do staff members have in ensuring that individuals are not harmed in the small group process? Under what circumstances is it best to problem-solve issues that arise in groups so that 
students experience conflict and its resolution, and under what circumstances is the conflict unable to be resolved and potentially destructive to the learning process?

\section{A Team Approach to Teaching and Curriculum Development and the Teacher's Role as Facilitator}

Staff are involved in the learning process as facilitators, consultants, guides, mentors, coaches, co-learners and finally, as assessors. Roles for 'teachers as facilitators' are to dialogue with learners, secure resources, evaluate outcomes, and promote critical thinking (Kolb, 1984). Boud and Miller (1996) suggested that facilitator was not an adequate term for the person in the experience-based classroom. Like Freire (1970), they described the teacher as an 'animator', a much more active role in acting with learners to assist them to work with and through their experience, to use their experience as a basis for further learning.

In both social work practice and experience-based learning, the engagement of the person's experience is essential to beginning the learning process; so too is seeing the person as self-determining and self-directing. It is essential to ensure that boundaries are firmly established so that the power differences, which are inevitable in the teacher/learner or social worker/client relationship, are not abused. The teacher in an experience-based program is a facilitator, mentor, and role model for students. This relationship has many common features with that of the social worker/client relationship, especially within the strengths perspective. The Newcastle model is consistent with this perspective in so far as it draws on the strengths, assets, and resources of both teachers and learners. It is this focus 
on strengths, which creates the context within small groups for creative, innovative learning, problem-solving, and critical thinking and reflection.

The switch from the role of facilitator to assessor presents dilemmas in terms of balancing competency or outcome-based and process-oriented learning. Although the program was not designed strictly on a competency-based training model, it does rely heavily upon a commitment to producing graduate social workers who are competent, able to demonstrate their competence, and who feel confident in their abilities while recognising the need for ongoing education and skills development throughout their career (English et al, 1994).

Through a team teaching approach, academic staff members are continuously engaged in an ongoing process of reflective practice as educators. The Newcastle team has developed a clear set of goals and strategies for the learning program to which all are committed. Differences can then be discussed within a framework of common goals. The course program is in a constant state of development, application, and review, and, as such, is action research based.

It is challenging to maintain a team approach to teaching. Universities foster competition rather than cooperation, reward individual rather than group achievement and encourage the cultivation of egos. Shared goals and time for group meetings are two principles that are fundamental to the ongoing team approach at the University of Newcastle. More attention needs to be given to the induction of new team members, so that they have a sense of belonging to the team. 


\section{Future directions}

As computer technology becomes more sophisticated and more generally available, there are likely to be more opportunities for the development of groupwork via the Internet. This was very successful in its trial with first year groups in the Newcastle program in 2000 and has the potential to be used more widely, especially as a tool to integrate field and campus learning more closely. In a paper that looked at the development and future of problembased learning in medical education, Camp (1996) noted that computers would become increasingly influential in education generally. As computer technology becomes more sophisticated there is likely to be more use of 'virtual case examples' and interactive programs that require clinical decision-making, and it is intended that the critical thinking web-site will be used in this way.

Camp (1996) also considered it likely that there would be growth in interdisciplinary approaches to learning, particularly in opportunities to learn in small interdisciplinary groups. There are many possibilities for social work to develop interdisciplinary programs at undergraduate level in the fields of health, law and justice, schools and education, politics, and economics. In Newcastle we are beginning interdisciplinary group programs with the health professions and with early childhood students.

\section{Conclusion}

This paper has described a relatively new social work education program developed by the Department of Social Work at the University of Newcastle in New South Wales, which 
pioneered problem-based learning in Australia. It presented Newcastle’s model as a unique example of experience-based teaching and learning that derives from the related philosophies and ideas of problem-based and experiential learning and processes for educating reflective practitioners with an appreciation for lifelong learning. The development of the model, the theory that underpins it and its core features were described, followed by challenges within an integrated and experience-based approach and future directions. Although the model is not without its problems, it is seen as an approach to education that is consistent with the values and processes of social work practice and is, at the same time, enjoyable for faculty and students. A satisfying outcome of our program has been to hear that graduates, and students on placement, are particularly valued in their workplaces for their capacity to present workshops and information to both practitioners and clients using an experience-based approach.

\section{References}

BOUD, D. (ed.) (1985) Problem-based learning in education for the professions (Sydney, Higher Education Research \& Development Society of Australasia).

BOUD, D. \& PASCOE, J. (1988) What is experiential learning? in J. Higgs (ed.) Experience-based learning (Sydney, The Australian Consortium on Experiential Education).

BOUD, D. \& KNIGHTS , S. (1996) Course design for reflective practice, in N. Gould \& I. Taylor (eds). Reflective learning for social work: research, theory and practice (Aldershot, Arena, Ashgate Publishing), pp.23-34. 
BOUD, D. \& MILLER, N. (eds). (1996) Working with experience: Animating learning (London, Routledge).

BRINER, M. (1999) Constructivism: The theories

(http://curriculum.calstatela.edu/faculty/psparks/theorists/501const.htm).

BROOKFIELD, S. (1987) Developing critical thinkers: Challenging adults to explore alternative ways of thinking and acting (San Francisco, Jossey-Bass Inc.).

BROWN, G. (1987) Effective teaching in higher education (Methuen, London).

BURGESS, H. (1992) Problem-led learning for social work: The enquiry and action approach (London, Whiting \& Birch).

CAMP, G. (1996) Problem-based learning: A paradigm shift or passing fad? Medical Education On-line (http://www.utmb.edu/meo/f0000003.htm).

DEWEY, J. (1916) Democracy and education: an introduction to the philosophy of education (New York, Free Press).

DEWEY, J. (1938) Experience and education (New York, Collier Books).

ENGLISH, B., GAHA, J. \& GIBBONS, J. (1994) Educating social workers for an uncertain future, in S. Chen, R. Cowdroy, A. Kingsland \& M. Ostwald (eds), Reflections on problem-based learning (Sydney, Australian Problem-based Learning Network), pp.279296.

FAURE, E. (1972) Learning to be (Paris, UNESCO).

FINUCANE, P., JOHNSON, S. \& PRIDEAUX, D. (1998) Problem-based learning: Its rationale and efficacy, Medical Journal of Australia, 168, pp.445-448. 
FLYNN, L. (1997) Social work students confront social justice issues through experiential learning. Australian Social Work, 50(4), pp.21-27.

FOOK, J. (1999) Critical reflectivity in education and practice, in J. Fook \& B. Pease (eds) Transforming social work practice (St Leonards, Allen \& Unwin) pp.195-208.

FREIRE, P. (1970) Pedagogy of the oppressed (New York, Continuum).

FREIRE, P. (1994) Pedagogy of hope (New York, Continuum).

GAMBRILL, E. (1997) Social work practice: a critical thinker's guide (New York, Oxford University Press).

GIBBONS, J. (1992) The teaching team: Small group process in social work education, Social Groupwork Monograph, 3, pp. 66-76.

GOLDSTEIN, H. (2001) Experiential learning: A foundation for social work education and practice (Forthcoming publication Washington, DC, CSWE).

JOHNSON, D., JOHNSON, R. \& SMITH, K. (1998) Active learning: Cooperation in the college classroom (Edina, MN, Interaction Book Co.).

KAUFMAN, D. \& FELDER, R. (2000) Accounting for individual effort in cooperative learning teams, Journal of Engineering Education, 89(2), pp.133-140.

KNEFELKAMP, L. \& SCHNEIDER, C. (1997) Education for a world lived in common with others, in R. Orrill (ed). Education and democracy: Reimagining liberal learning in America (New York, College Entrance Examination Board) pp.327-343.

KNOWLES, M. (1975) Self-directed learning: A guide for learners and teachers (New York, Association Press). 
KOLB, D. (1984) Experiential learning: Experience as the source of learning and development (Englewood Cliffs, NJ, Prentice Hall, Inc).

LASCH, C. (ed). (1965) The social thought of Jane Addams (Indianapolis, Bobbs-Merrill). MAUDSLEY, G. \& STRIVENS, J. (2000) Promoting professional knowledge, experiential learning and critical thinking for medical students, Medical Education 2000, pp. 535-544. PLATH, D., ENGLISH, B., CONNORS, L. \& BEVERIDGE, A. (1999) Evaluating the outcomes of intensive critical thinking instruction for social work students, Social Work Education, 18 (2), pp.207-217.

ROBINSON, V. (1930) A changing psychology in social casework (University of Carolina Press, Chapel Hill).

ROSSITER, A. (2001) Innocence lost and suspicion found: Do we educate for or against social work? Critical Social Work

(http://www.criticalsocialwork.com/01_1_innocence_rossiter.html).

SCHÖN, D. (1983) The reflective practitioner (Jossey Bass, San Francisco).

SCHÖN, D. (1987) Educating the reflective practitioner (Jossey Bass, San Francisco).

TAYLOR, I. (1997) Developing learning in professional education: Partnerships for practice (Open University and SRHE Press).

\section{Acknowledgement}

Brian English, Jo Gaha, Jill Gibbons, Liane Flynn and Debbie Plath developed the Newcastle model of experience-based social work education between 1990 and 1993. In 1993, this teaching team received an award for excellence in teaching from the University of Newcastle. The first graduates of the four-year degree 
entered the workforce in 1995. Many social workers, practitioners as well as academics, have continued to develop the model which is seen as a work in progress.

\begin{abstract}
About the authors
Jill Gibbons was one of the first practitioners to join the Newcastle team in 1991 and has played a key role in developing this unique education model. She is particularly interested in how students learn critical thinking skills and constantly challenges the team to stay with its experiential focus and to continue with the challenge of improving the model based on our experience of teaching it.

gibbons@socwork.newcastle.edu.au
\end{abstract}

Mel Gray joined the Department of Social Work at the University of Newcastle in 1999, replacing Brian English who became (and remains) Deputy Vice-Chancellor of the university in 1997. She immediately appreciated the gem Newcastle had created and encouraged staff to write about what they had done so as to disseminate it more widely. This paper is part of this process as Jill and Mel have worked together to articulate the theoretical underpinnings of the model and to describe how it is implemented.

melgray@mail.newcastle.edu.au

The University of Newcastle, Department of Social Work, University Drive, Callaghan 2308, New South

Wales, Australia 


\section{Experience}

1. Learning trigger - which must

engage the student's experience.

2. Task presentation - group \& self

evaluation and feedback
Apply new learning to task

New learning will be required to

complete task

\section{4}

Self-directed \& group

learning

Given focus with learning goals \&

individual and group tasks.

Critical appraisal of information

from reading and research.

\section{Note reactions}

Feelings, thoughts, physical

symptoms

\section{Identify learning needs}

What do I need to know to respond to this situation?

Reading \& research.

\section{Critically reflect}

Examine own values, biases, and assumptions. Question.

Think laterally. Listen to

others \& challenge each other in the group environment.

FIG. 1. Newcastle's adaptation of Kolb’s (1984) model 


\begin{tabular}{|c|c|c|}
\hline Dimension & Experiential & Didactic \\
\hline Motivational theories & $\begin{array}{l}\text { Draws on achievement goal theory, a major new } \\
\text { direction in motivational research that focuses on } \\
\text { mastery and intrinsic goals }\end{array}$ & $\begin{array}{l}\text { Performance goal theory focuses on } \\
\text { presence or absence of motivation and } \\
\text { emphasises performance and extrinsic } \\
\text { goals (normatively defined success; } \\
\text { comparative standards) }\end{array}$ \\
\hline Theoretical underpinning & Uses a socio-cognitive framework & Social learning theory \\
\hline Type of education model & $\begin{array}{l}\text { Learning model - how students learn - } \\
\text { experiential, inductive, bottom up; learning is an } \\
\text { active and interactive process; students } \\
\text { experience and engage in learning }\end{array}$ & $\begin{array}{l}\text { Teaching model - what to teach - } \\
\text { knowledge is imparted in an organised, } \\
\text { sequential and controlled manner aimed at } \\
\text { achieving certain required objectives }\end{array}$ \\
\hline Patterns in learning strategies & $\begin{array}{l}\text { Process is paramount -Focuses on way in which } \\
\text { students learn - how they approach, engage in } \\
\text { and respond to achievement related activities } \\
\text { (learning tasks) }\end{array}$ & $\begin{array}{l}\text { Outcome - task accomplishment or } \\
\text { completion is emphasised over process e.g. } \\
\text { learning in order to pass the exam }\end{array}$ \\
\hline Approach to learning tasks & $\begin{array}{l}\text { Co-operative/participatory (peer collaboration), } \\
\text { self-directed (self-monitoring/ regulating), self- } \\
\text { instructional; Individuals and learning (peer) } \\
\text { group seen as resources }\end{array}$ & $\begin{array}{l}\text { Competitive, individualistic; personal } \\
\text { ability, competition and individual } \\
\text { comparison predominate; learning seen as a } \\
\text { means to an end }\end{array}$ \\
\hline $\begin{array}{l}\text { Problem-solving / learning } \\
\text { strategies used }\end{array}$ & $\begin{array}{l}\text { Deep learning strategies: Reviewing material not } \\
\text { understood, asking questions, seeking } \\
\text { explanation, making connections between present } \\
\text { and past experiences, persistence, deeper } \\
\text { processing and the use of multiple sources }\end{array}$ & $\begin{array}{l}\text { Superficial, rote learning, information } \\
\text { acquisition, repetition or reproduction of } \\
\text { lecturer's notes, guessing, copying, } \\
\text { skipping questions }\end{array}$ \\
\hline $\begin{array}{l}\text { Dominant teaching style/ } \\
\text { strategies }\end{array}$ & $\begin{array}{l}\text { Facilitative - generation of creative, novel, } \\
\text { varying, meaningful, challenging learning tasks } \\
\text { adapted to student interest, current developments } \\
\text { and authentic problems. Active strategies for } \\
\text { integrating information, monitoring } \\
\text { comprehension, fostering competence, providing } \\
\text { timely support and feedback, and constructing } \\
\text { meaning. Student-centred }\end{array}$ & $\begin{array}{l}\text { Didactic, deductive, top down } \\
\text { 'Spoonfeeding' } \\
\text { Teacher controlled }\end{array}$ \\
\hline Dominant learning style & Learning a process of discovery & Rote learning \\
\hline Reactions to learning & Interesting and enjoyable & Boredom and disinterest \\
\hline Assessment of learning & $\begin{array}{l}\text { Learning based; skill development (effort } \\
\text { associated with greater feelings of competence); } \\
\text { compete with own performance standard rather } \\
\text { than with others; comparative feedback/ } \\
\text { evaluation avoided; focus on personal progress }\end{array}$ & $\begin{array}{l}\text { Outcome (standard) based; demonstration } \\
\text { of competency; self worth linked to ability } \\
\text { to perform (considerable performance } \\
\text { anxiety); measure performance relative to } \\
\text { peers; rewards highest achievers }\end{array}$ \\
\hline Classroom atmosphere & $\begin{array}{l}\text { Creative, supportive, interactive, encourage } \\
\text { mastery - positive attitudes (strengths based), } \\
\text { encourage personal autonomy, choice, control } \\
\text { and self-responsibility }\end{array}$ & Traditional lecture situation \\
\hline Educator's role & Facilitator, resource, guide, role-model & Lecturer, evaluator, assessor \\
\hline Failure attributed to & Faulty learning strategy & Insufficient effort or ability \\
\hline Outcome & Resourcefulness & Learned helplessness \\
\hline
\end{tabular}

FIG. 2. Comparison between experiential and didactic learning models 


\section{The process of self-directed and group facilitated or negotiated learning}

- A trigger opens the learning experience. The trigger must engage the experience of the students. The trigger may be a speaker, e.g. a practitioner with first hand experience of the issue or a consumer, an agency visit, a simulated exercise, a current documentary or newsclip, and the like.

- After exploring their reactions to the trigger experience, students are provided with learning goals and a learning task or assignment. These are set by the lecturer/teacher and reflect, in as far as possible, current issues within the wider social context.

- Working in small groups, students negotiate with one another the way in which they will approach the learning task and draw up and enter into a learning contract with one another. This negotiated contract will include the way in which the group facilitator (lecturer) will be used as a resource for the learning process. As stated by Burgess (1992), the students 'ask questions, formulate learning objectives, decide on the means of learning, critically evaluate resources, and review their own learning' (p.13).

- The students, either within their groups or individually, depending on the particular assignment (or piece of assessment), present their learning in the classroom. They use a variety of presentations and visual means, such as posters, graffiti walls, video clips, role-plays, talks and the like and/or submit a written assignment for marking. The emphasis is on creativity and innovation.

- Each learning unit ends with a debriefing session when the learning experience is evaluated and reinforced and lessons for future learning outlined.

FIG. 3. The process of self-directed and group facilitated or negotiated learning 


\section{Targeted development of critical thinking skills}

- $\quad$ Freeing up students' creativity and lateral thinking.

- Identifying, exploring and challenging values, assumptions and beliefs.

- $\quad$ Exploring personal experiences of questioning, having views and how these might have been suppressed.

- $\quad$ Acknowledging the need to allow for different audiences.

- $\quad$ Preparation for conflict and debate - engaging in conflict, constructing good argument, identifying bad argument.

- $\quad$ Giving and receiving useful feedback to enhance learning.

- Identifying different 'ways of knowing' - intuition, experience, science, beliefs, ideology, theory, and research.

- $\quad$ Ethical reasoning.

- $\quad$ Clinical judgement - identifying alternatives, making sound practice decisions.

- Social work research - the development of knowledge.

FIG. 4. Targeted development of critical thinking skills in the Newcastle approach to experience-based learning 


\begin{tabular}{|c|c|c|}
\hline Characteristic & Description & Facilitator's role \\
\hline Time and resource intensive & $\begin{array}{l}\text { Maximum group size of } 15 \\
\text { Long teaching sessions of two to three hours } \\
\text { duration }\end{array}$ & $\begin{array}{l}\text { One group facilitator for } 15 \text { students; } \\
\text { experienced group facilitators are needed }\end{array}$ \\
\hline Teachers must be creative & Varied tasks and assignments & Need to stimulate interest and attention \\
\hline $\begin{array}{l}\text { Need clear boundaries between } \\
\text { personal and educational goals }\end{array}$ & Risk of confused educational and personal goals & $\begin{array}{l}\text { Skill is needed because the intimacy and } \\
\text { safety of the small group encourages students } \\
\text { to reveal personal information }\end{array}$ \\
\hline $\begin{array}{l}\text { Suited to professional disciplines which } \\
\text { require a combination of knowledge, } \\
\text { value and skill }\end{array}$ & Teaches students to think on their feet & $\begin{array}{l}\text { Facilitator models appropriate } \\
\text { communication and problem-solving } \\
\text { behaviour }\end{array}$ \\
\hline $\begin{array}{l}\text { Group provides a safe environment for } \\
\text { learning }\end{array}$ & $\begin{array}{l}\text { Need an environment for freedom of expression } \\
\text { as the sharing of diverse beliefs and opinions } \\
\text { provides an enriching experience conducive to } \\
\text { learning }\end{array}$ & $\begin{array}{l}\text { Facilitator models acceptance and tolerance } \\
\text { of diversity and attempts to enable students } \\
\text { to justify their beliefs and values }\end{array}$ \\
\hline $\begin{array}{l}\text { Focuses on strengths and resources } \\
\text { students bring to the group }\end{array}$ & Values past experiences/prior learning & $\begin{array}{l}\text { Facilitator enables students to relate } \\
\text { knowledge and experience from a variety of } \\
\text { sources and apply it to new learning }\end{array}$ \\
\hline Positive feedback & $\begin{array}{l}\text { Feedback needs to be honest but non- } \\
\text { threatening so as not to undermine students' } \\
\text { confidence }\end{array}$ & $\begin{array}{l}\text { Structured introductory and feedback } \\
\text { sessions begin and end each learning unit }\end{array}$ \\
\hline Effective means of teaching theory & $\begin{array}{l}\text { Structured class exercises can be designed for } \\
\text { students to learn diverse theories within } \\
\text { learning units }\end{array}$ & $\begin{array}{l}\text { Facilitator structures the learning unit to } \\
\text { facilitate theoretical knowledge and } \\
\text { understanding }\end{array}$ \\
\hline $\begin{array}{l}\text { Offers flexibility in developing learning } \\
\text { around current issues and concerns }\end{array}$ & $\begin{array}{l}\text { Learning units can be designed around topical } \\
\text { issues relating to the learning topic }\end{array}$ & $\begin{array}{l}\text { Facilitators ensure that topical issues are } \\
\text { integrated into the learning unit }\end{array}$ \\
\hline Model intervention strategies & $\begin{array}{l}\text { Learning units can be structured to encourage } \\
\text { students to develop intervention strategies } \\
\text { around the issue or concern }\end{array}$ & $\begin{array}{l}\text { Facilitators design feedback and presentation } \\
\text { sessions to encourage students to develop } \\
\text { appropriate intervention strategies }\end{array}$ \\
\hline Equips students with research skills & $\begin{array}{l}\text { Learning units require students to identify, } \\
\text { locate and collect appropriate information }\end{array}$ & $\begin{array}{l}\text { Facilitators provide supportive structures, } \\
\text { e.g. library support, electronic discussion } \\
\text { lists }\end{array}$ \\
\hline Students learn about group dynamics & $\begin{array}{l}\text { Students contract with one another and with the } \\
\text { Facilitator to accomplish group tasks }\end{array}$ & $\begin{array}{l}\text { Facilitator provides support and guidance } \\
\text { when needed }\end{array}$ \\
\hline Students learn about group roles & $\begin{array}{l}\text { Natural leaders emerge and groups 'allow' them } \\
\text { to take on a directive role }\end{array}$ & $\begin{array}{l}\text { Facilitator encourage students to share roles } \\
\text { and take equal responsibility for group tasks }\end{array}$ \\
\hline $\begin{array}{l}\text { Risk that some students do more than } \\
\text { others }\end{array}$ & $\begin{array}{l}\text { Group bears the responsibility to ensure that } \\
\text { work is evenly distributed }\end{array}$ & Facilitator remains aware of this risk \\
\hline $\begin{array}{l}\text { Risk that only positive feedback is } \\
\text { given }\end{array}$ & $\begin{array}{l}\text { The overall positive tone of the feedback } \\
\text { sessions might discourage quieter students to } \\
\text { reserve their comments when they would be of } \\
\text { value to group learning }\end{array}$ & $\begin{array}{l}\text { Facilitator attempts to ensure that all students } \\
\text { participate in feedback sessions remaining } \\
\text { sensitive to underlying tensions and } \\
\text { dynamics }\end{array}$ \\
\hline Lack of structure and direct information & $\begin{array}{l}\text { Since the didactic model is not being used, } \\
\text { sometimes students feel that insufficient } \\
\text { information is provided }\end{array}$ & $\begin{array}{l}\text { Facilitator attempts to provide clear } \\
\text { instructions and background information on } \\
\text { learning assignments and identify and fill } \\
\text { gaps in learning }\end{array}$ \\
\hline
\end{tabular}

FIG. 5. Characteristics of self-directed small group experience-based learning model 
APPENDIX 1: BACHELOR OF SOCIAL WORK DEGREE STRUCTURE ${ }^{1}$

\begin{tabular}{|c|c|c|}
\hline Year 1 & & Credit Points \\
\hline SWRK101 & Introduction to Social Work & 20 \\
\hline SOCA101 & Introduction to Sociology \& Social Anthropology & 10 \\
\hline SOCA102 & Introduction to Sociology \& Social Anthropology & 10 \\
\hline PSYC101 & Psychology Introduction I & 10 \\
\hline \multirow[t]{2}{*}{ PSYC102 } & Psychology Introduction II & 10 \\
\hline & 2 Elective subjects at 100 level & 20 \\
\hline \multicolumn{3}{|l|}{ Year 2} \\
\hline PHIL258 & Ethical Issues & 10 \\
\hline SWRK203 & Field Education 1 & 20 \\
\hline \multirow[t]{2}{*}{ SWRK210 } & Social Work Theory and Practice 1 & 40 \\
\hline & Directed electives - select one of the following & \\
\hline ABOR111 & Introduction to Aboriginal Studies & 10 \\
\hline HIST101 & Foundations of Australian Society & 10 \\
\hline HIST102 & Australia in the Twentieth Century & 10 \\
\hline \multicolumn{3}{|l|}{ Year 3} \\
\hline LAW101 & Foundations of Law & 10 \\
\hline SWRK307 & Regional Social Policy and Planning & 10 \\
\hline SWRK303 & Field Education II & 20 \\
\hline SWRK310 & Social Work Theory and Practice 2 & 40 \\
\hline \multicolumn{3}{|l|}{ Year 4} \\
\hline SWRK403 & Field Education III & 20 \\
\hline \multirow[t]{2}{*}{ SWRK410 } & Social Work Theory and Practice 3 & 40 \\
\hline & Elective subjects at 200 level or higher & 20 \\
\hline
\end{tabular}

${ }^{1}$ Only the four-year social work course is taught experientially. 


\title{
APPENDIX 2 \\ EXAMPLE OF A LEARNING UNIT USING THE NEWCASTLE MODEL
}

\section{SWRK 210 - SOCIAL WORK THEORY AND PRACTICE - LEARNING UNIT 1}

\begin{abstract}
Themes: Critical thinking skills, applying theory to social work practice, ecological systems theory,
\end{abstract} community work, substance use

\section{LEARNING GOALS}

The learning goals are to:

1. Develop skills in critical thinking and in particular to:

- Recognise the importance of critical thinking to social work practice

- Be able to analyse a situation from more than one perspective

- Identify how ideology determines different points of view

- Consider the audience, and how it influences the presentation

- Examine the qualities of argument and engage in debate.

2. Understand the role of theory in social work and demonstrate a critical understanding of ecological systems theory and community work theories and models. This includes an introduction to debates in community work theory.

3. Understand the ways in which substance use, drug taking and addictions are socially constructed, and the range of possible roles for social workers in this area of practice.

4. Examine and explore your own values and beliefs about substance use and about communities, and to place these in the context of core social work values.

5. $\quad$ Consider the ways in which a community may be defined.

6. Demonstrate an understanding of the specific social work intervention of community work and be able to describe the process of applying a community work strategy. To explore how the social worker applies interpersonal and group work skills, and works with conflict in undertaking community work.

7. Begin to identify how power and influence affect individuals, groups and communities to achieve or obstruct social justice in society.

8. Develop further skill in working as part of a team and producing work as part of a group.

\section{Unit Structure and Tasks}

This learning unit runs for eight weeks. During this time you will work through a range of class exercises aimed at developing skills in critical thinking, an understanding of ecological systems theory and community work theories and skills. The context used for the learning unit is substance use. Because it can also be an addiction, gambling is one of the behaviours that will be considered in this learning unit. Students are expected to attend all classes, to research and prepare material outside of class time and to participate in group tasks and class discussion in order to attain a satisfactory result for the unit. The critical thinking skills acquired through the unit will continue to be developed in future learning units and will become part of the assessment criteria in all work submitted in the remainder of the degree. Please remember that the individual and group tasks aim to focus your reading and learning. Please make use of class time and staff consultation to ask questions about any areas that you find difficult or confusing.

\section{Group Task}

The NSW Government has launched a Drug and Community Action Strategy, which is to establish Community Drug Action Teams in local government areas to develop action plans to respond to the adverse effects of drugs. Council has convened a public forum to discuss issues relating to substance use in the local government area and to form the Community Drug Action Team. The team is to involve such people as local 
government representatives, police local area commanders, school principals, area health staff, and representatives of youth and community organisations and concerned residents.

You have volunteered to be members of the Community Drug Action Team in your local area and are to work with Council's community worker to develop a strategy to address substance use issues. The community worker has decided to use one of the following models to develop their strategy:

- Community education

- Social planning

- Community development

- Social action

The Community Drug Action Team has contracted to present its proposed strategy back to the public forum. Your strategy will need to address:

- The range of ideological perspectives in the community

- The role of the community worker in implementing the strategy

- The skills she might use

- The way in which the community will be engaged as participants.

Date due: The strategies will be presented in class time on Monday 3 April, Tuesday 4 April and Wednesday 5 April, 2000. Each presentation should take a maximum of 25 minutes. After each presentation the class will critically review each strategy as a community work intervention. These reviews are intended to further the learning of the whole class about community work theory and skills.

Graded: Satisfactory/ Unsatisfactory

Your work on the group task will inform your individual task.

\section{Individual Task}

In your position as a Local Government Community Worker you receive regular professional supervision. In preparation for a supervision session you have reviewed your recent experience of working on the issue of substance use with the Community Drug Action Team. Your review includes reflections about the social construction of substance use, the group experience, theoretical approaches, professional skills, and value questions. The review should be prepared as you progress with the learning unit and is to be submitted in two parts.

\section{Part I: Social Construction of Substance Use}

To inform your work with the Community Drug Action Team you have selected a current issue concerned with substance use (possible issues include teenage drinking, ecstasy, injecting rooms, alcohol, cigarette smoking) or with gambling. You have collected five (5) examples of Australian writing about this issue which target different audiences. Possible sources of such material have included:

- A popular newspaper

- A 'serious' newspaper

- Letters to the editor in these papers

- The internet

- A professional journal

- An alternative source - e.g. Green left Weekly

- A government policy or report

Your written review incorporates an analysis of the different forms of writing in terms of the apparent values and ideologies of the publication or source, the intended audience, and the author. You include reflections on how these have influenced the approach taken in the material. 
Length: 3 x 4 pages double spaced, minimum 12-point font.

\section{Part II: Experience with the Community Drug Action Team}

In this section of your review you reflect on the following components of your experience with the Community Drug Action Team.

\section{Group Experience}

- Your experience of your group's process as you worked to develop a strategy to address substance use issues. Your reflections are to draw on your knowledge of group dynamics and group process.

\section{Theoretical Perspectives}

- Your understanding of ecological systems theory and your analysis of its relevance to the issue of substance use.

- $\quad$ Different community work approaches and their application to this issue.

\section{Professional Role/Skills}

- $\quad$ The role and skills you employed in working with the Community Drug Action Team.

\section{Personal Values}

- The challenge to your personal values of your learning through this project.

Length: 8 x A4 pages doubles spaced minimum 12-point font.

Criteria for assessment (parts I and II):

- Appropriate referencing

- Demonstrated reading and integration of literature

- Discussion of each aspect

- Demonstrated understanding of group process, community work theory and practice, ecological systems theory

- $\quad$ Skills in critical analysis

- Demonstrated personal reflection

- Organisation, presentation and structure 